\title{
The Position, Election and Powers of the President of the Republic of Estonia
}

\author{
TADEJ DUBROVNIK
}

\begin{abstract}
Estonia has a typical parliamentary system in which the President of the Republic is indirectly elected. This paper deals with the position of the President of the Republic of Estonia, with the election of the President, and with his powers. Particular attention is paid to standard functions and powers in the legislative and executive realms. In addition, the extraordinary powers of the President of the Republic are also mentioned. The largest chapter of this paper describes the election of the President of the Republic. The Estonian regulation is specific because it allows up to five rounds of elections. The President of the Republic is elected by the Parliament in the first three rounds of elections. If no candidate receives a majority of votes, a special electoral body is formed (it is made up of the Members of Parliament and the representatives of local self-governing communities) to elect the President of the Republic in the fourth round of elections and, if necessary, in the fifth round of elections. The local council of each local community elects at least one representative to this body. The number of the representatives an individual local community will have depends on the number of citizens living in its area. In the end, the paper presents the responsibilities of the President of the Republic.
\end{abstract}

KEY WORDS: • electins $\bullet$ President of the Republic of Estonia • local self-government $\bullet$ parliament $\bullet$ Estonia

CORRESPONDENCE ADDRESS: Tadej Dubrovnik, Institute for Legal Solutions for Information Society, Gorkega ulica 51, SI-2000 Maribor, Slovenia, e-mail: tadej.dubrovnik@gmail.com. 


\section{Introduction}

This paper deals with the position of the President of the Republic of Estonia, an EU Member State, where there is a parliamentary system based on the principle of the separation of powers. The executive power is divided between the Government as an actual holder of power and the Head of the State who is merely a symbolic head of the executive branch of government.

In the parliamentary system, the President of the Republic, as the Head of the State, has very limited powers that are primarily of a representative nature. The President represents the country at home and abroad, promulgates laws (where, as a rule, the President has the right of a suspensive veto), commands the armed forces, gives mandate for forming a government, appoints and recalls ambassadors, accepts the credentials and letters of recall of foreign diplomatic representatives, issues instruments for the ratification of international treaties, awards decorations, issues pardons, etc.

The parliamentary systems and the position of the Head of the State differ among themselves in modern constitutional orders. So, for example, among the Central and Eastern European EU Member States, Slovenia is the only country in which the President of the Republic has no right of suspensive veto. And beside Estonia, Slovenia does not know the institute of the countersignature either.

This paper deals with the position of the President of the Republic of Estonia, with the election of the President, and with his powers. Particular attention is paid to standard functions and powers in the legislative and executive realms. The extraordinary powers of the President of the Republic are not dealt with in detail because, as a rule, the President of the Republic exercises these powers in the event of war or a state of emergency when the Parliament cannot meet. The largest chapter of this paper describes the election of the President of the Republic. The Estonian regulation is interesting and specific because it allows up to five rounds of elections. The President of the Republic is elected by the Parliament in the first three rounds of elections. If no candidate receives a majority of votes, a special electoral body is formed (it is made up of the Members of Parliament and the representatives of local self-governing communities) to elect the President of the Republic in the fourth round of elections and, if necessary, also in the fifth round of elections. In the end, the paper presents the responsibilities of the President of the Republic.

The purpose of this paper is to provide fundamental pieces of information as well as the most relevant and specific information on the position of the Head of the State in the Republic of Estonia. 


\section{The Position of the President of the Republic}

In accordance with the Constitution, Estonia has a parliamentary system based on the principle of the separation of powers into the legislative, judicial and executive branches of government. ${ }^{1}$ The latter is shared between the Government and the Head of the State. ${ }^{2}$

The President of the Republic is the Head of the State of Estonia who represents the country abroad. ${ }^{3}$

Regarding the replacement of the President of the Republic, Article 83 of the Constitution provides that the President of the Parliament temporarily performs the duties of the President of the Republic. While acting as the President of the Republic, the President of the Parliament may not exercise his powers as a Member of Parliament. Therefore, his function shall be suspended. Without the consent of the Supreme Court (as the highest judicial body, the Supreme Court is also competent to give a constitutional judicial review) ${ }^{4}$, the President of the Parliament, acting as the President of the Republic, may neither call an extraordinary election nor refuse to promulgate laws. If the President of the Republic is unable to perform his or her duties for more than three consecutive months, the Parliament shall elect a new President of the Republic. The office of the President of the Republic shall terminate also upon his or her resignation, a final judgment of conviction, death and upon assuming the office of the new President (Article 82 of the Constitution).

Upon assuming the office of the President of the Republic, his or her membership shall be suspended in a political party (Article 84 of the Constitution). In contrast to this, the Slovene Constitution does not prohibit the President of the Republic from being a formal member of a political party during the duration of his or her term of office. However, according to the Slovene legal theory, the President as a representative of the state must operate at a level which is above party politics. ${ }^{5}$

The Estonian President shall be elected for a five-year term, but not for more than two consecutive terms. ${ }^{6}$ It should be pointed out that in some constitutional orders, it is provided by the statute that no person may be elected as President more than twice (e.g., in Poland, Hungary, Romania and Bulgaria). Other countries know only a restriction that the same person may not be elected more than twice consecutively, which means that he or she can be re-elected as President of the Republic later on, i.e., "after an interruption" (e.g., in Slovenia, Estonia, Lithuania, Latvia, Slovakia and in the Czech Republic).

By way of exception, the term of the office of the President of the Republic can be longer or shorter than five years. If the term of office of the President of the Republic expires during a state of war or emergency, his or her term of office shall terminate at the end of such a state. In the case of a possible extension of the term 
of office, the election of the new President of the Republic shall be held no later than three months after the end of the war or state of emergency (Article 131 of the Constitution). A shorter term of office is the consequence of the permanent impediment, resignation from office, death or other termination of the office of the President. In this case, the Parliament shall elect a new President of the Republic within 14 days after the termination of the office of the former President.

\section{Election of the President of the Republic}

The President of the Republic shall be elected by Parliament (the Riigikogu is a unicameral Estonian parliament of 101 members). In a specific case, he or she shall be elected by a special electoral body. The election procedure is rather complicated because there can be up to five rounds of elections. In the event that the President is not elected by the Parliament in the first three rounds, a special electoral body ${ }^{7} \mathrm{~s}$ formed. The countries in which the President of the Republic is elected by Parliament require a different majority of votes for the President of the Republic to be elected. ${ }^{8}$ Thus, an absolute majority is required in the Czech Republic and in Latvia, whereas Hungary and Estonia require that a two-third majority of the votes should be cast by the Members of Parliament to elect the President of the Republic.

The basic rules concerning the election of the President of the Republic are included in the Constitution, in Chapter 5 (Articles 77 to 85). Presidential elections are governed in detail by the Election of the President of the Republic Act (1996).

\subsection{Election of the President of the Republic by Parliament}

The President of the Republic shall be elected by secret vote. Each Member of Parliament shall have one vote. A candidate for President can be nominated by one fifth of the Members of Parliament (21 Parliament Members out of 101) where an individual member may vote in favour of only one candidate. A candidate is elected if at least two-thirds of all the Members of Parliament voted in favour of him or her. If no candidate receives the required majority, the second round of elections shall be held on the following day. Prior to the second round of voting, new candidates shall be nominated. If no candidate receives a two-third majority of votes, a third round of elections shall be held on the same day. It shall be held between the two candidates with most votes from the second round. The Act specifically governs the situation in which two candidates share the second place due to an equal number of votes received in the second round of voting. Then the elder candidate of them and the candidate who has taken the lead will be ranked in the third round of elections. If only one candidate who received no adequate majority of votes had participated in the second round of elections, then it shall be voted only on him or her in the third round of elections. The candidate will be elected if he or she receives at least two-thirds of the votes cast by the 
Members of Parliament in the third round of elections. If the President of the Republic is not elected even in the third round of elections, the President of the Parliament shall convene an electoral assembly within one month.

\subsection{Election of the President of the Republic by Electoral Body}

If the Parliament fails to elect the President of the Republic, a special electoral body shall elect him or her. This body is made up of the Members of Parliament and the representatives of local self-governing communities. A day after the third round of elections in the Parliament, the National Election Committee sends the local communities a notice of the number of the representatives who will represent them in the electoral body. The representative body of each local self-governing community elects at least one representative. The number of the representatives a local community will have depends on the number of citizens who live on its territory, and are entered on the electoral roll. The state on the first day of the year when the presidential election is held is taken into account. In accordance with law;

- 1 representative belongs to the local community in which there are up to 10,000 citizens who have the right to vote;

- 2 representatives belong to the local community in which there are from 10,001 to 50,000 citizens who have the right to vote;

- 4 representatives belong to the local community in which there are from 50,001 to 100,000 citizens who have the right to vote;

- 10 representatives belong to the local community in which there are more than 100,000 citizens who have the right to vote.

To facilitate the understanding of the above mentioned information, it needs to be pointed out that in Estonia there are 227 municipalities: 33 urban municipalities (linn) and 194 rural municipalities (vald). There are 32 municipalities under 1000 population and there are only 3 municipalities with a population of over 50,000 inhabitants. More than half of the Estonian municipalities have fewer than 2000 local residents. ${ }^{9}$

In elections in 1996, the electoral body had a total of 374 members (273 representatives of local communities). In 2001, it was made up of 367 members (out of which 266 members were representatives of local communities). And in 2006, the electoral body had 246 representatives of local communities and 101 Members of Parliament, altogether 347 members. ${ }^{10}$

Regarding the representatives of local communities who will be the members of the electoral body, the Act provides that they must be the citizens of Estonia and the members of the local government council. However, they must not be the Members of Parliament. Local government councils must elect their representatives who will represent them in the electoral body no later than 7 days before the day of voting on the candidates for the President of the Republic. 
At the electoral assembly, the Parliament introduces those two presidential candidates who participated in the third round of voting in the Parliament. New candidates can also be nominated by at least 21 members of the electoral body in which an individual member may vote for only one candidate. The candidate who obtains the majority of the votes cast is elected the President of the Republic. If no candidate receives the necessary majority in the first round of voting in the electoral body, then a second round of voting shall be held on the same day. For the second round of voting in the electoral body, the names of the two candidates who received the largest number of votes in the first round of voting shall be entered on the ballot paper. The candidate who receives the majority of votes cast is elected. If two candidates receive an equal number of votes in the first round of voting in the electoral body and they share second place, the name of the elder candidate or the names of the elder candidates shall be entered on the ballot paper for the second round of voting. However, if only one candidate participated in the first round of voting and did not receive the necessary majority, then it shall be voted only on this candidate in the second round of voting in the electoral body.

In the presidential elections in 1996, even after three rounds of elections in the Parliament, no candidate achieved the required majority. The candidate managed to collect more than half of the votes of the electoral body members only in the second round of voting. A similar situation occurred also in the elections of $2001^{11}$ and then in 2006 when no candidate received the two thirds of the votes of all the Members of Parliament in the first three rounds of voting in the Parliament. The President of the Republic was elected by a special electoral body not earlier than in the second round of voting.

An Estonian citizen since birth who has attained 40 years of age may be elected the President of the Republic. Most EU Member States also determine the lower age limit for the acquisition of the passive right to vote, i.e., the right to be elected president. However, the Slovene constitutional order stands out due to its equalizing the conditions for the acquisition of active and passive voting rights. A Slovene citizen who attained 18 years of age on the day of the election may be elected President of the Republic. In addition to a higher age limit, the countries as a rule also set up other stringent conditions for the acquisition of the passive right to vote. Thus, a permanent residence is required in some countries (Romania, Slovakia), or the candidate is required to have been living in the country for the last few years (Lithuania, Bulgaria), or the candidate is required to have no dual citizenship (Latvia, Bulgaria), or the candidate must be a citizen since birth in the country in which he or she stands as a candidate for the President of the Republic (Estonia, Bulgaria).

Regarding presidential election deadlines, the Constitution provides that regular elections shall be held within 60 days and no later than 10 days prior to the end of the term of office of the President of the Republic. If the Parliament does not elect 
the President of the Republic in the third round of elections, the electoral body shall elect him or her within one month. In the event that no candidate is elected by the electoral body, a new presidential election shall be held within 14 days.

Prior to taking up his or her office, the President of the Republic shall take the oath before the Estonian Parliament.

\section{The Powers of the President of the Republic}

The chapters below give detailed descriptions of the standard duties of the President of the Republic, his or her powers in the legislative and executive realms, and the extraordinary powers of the President of the Republic.

\subsection{Standard Duties}

Under the Constitution, the President of the Republic is the Head of the State of Estonia and the supreme commander of its defence forces (Article 78). The President of the Republic (in cooperation with the Government) represents the Republic of Estonia in international relations. Upon the Government's proposal, the Estonian President shall: appoint and recall diplomatic representatives of the Republic, receive the credentials of foreign diplomatic representatives, award decorations and honorary titles, make decisions on pardons (Article 78 of the Constitution).

\subsection{Powers in the Legislative Realm}

The President of the Republic promulgates laws. However, the President has the right of suspensive veto. So, the President may require from the Parliament to decide once again on a law. The President of the Republic can use this right when he or she believes there are reasons and arguments on the basis of which the Parliament needs to reconsider a law one more time. The right of suspensive veto or, by way of exception, the right of absolute veto is undoubtedly the most efficient way to enforce the President's influence on the content of a law adopted by the Parliament (Kaučič, 1995:261). Within 14 days, the Estonian President may return a law to the Parliament for reconsideration. If the unchanged wording of the law is readopted by a simple parliamentary majority, the President of the Republic may propose to the Supreme Court to determine whether the law is in accordance with the Constitution (a constitutional veto), or the President promulgates this law. In other words, the Estonian President has the right of constitutional veto, but he or she must first resort to the legislative veto option. If the court ascertains that the law is not inconsistent with the Constitution, then the President of the Republic must promulgate it. In Article 105, the Constitution provides that the President of the Republic has no right of veto with regard to the law approved by the people in a referendum. The President is obliged to promulgate such a law immediately. The countries, in which the President of the Republic has a right of suspensive veto, 
prescribe a different majority of votes needed for adopting the unchanged wording of the law when the Parliament retakes votes on this. In addition to Estonia, a simple parliament majority is required also in Latvia, Romania and Hungary. An absolute majority is required in Bulgaria, Lithuania, the Czech Republic, and in Slovakia (Dubrovnik, 2008:56). It should be pointed out that in contrast to other Eastern European countries that are EU Member States, the Slovene President has no right of suspensive veto ${ }^{13}$ within the legislative procedure.

During the term of office of the Parliament from 1992 to 1995 (Riigikogu VII) and from 1995 to 1999 (Riigikogu VIII), the Estonian President returned 33 laws to the Parliament for reconsideration. The President filed a request for constitutional review of laws in eight cases in which the Supreme Court ascertained that seven laws were inconsistent with the Constitution. During the term of office from 1999 to 2003 (Riigikogu IX) and from 2003 to 2007 (Riigikogu X), the President of the Republic refused to promulgate laws in 18 cases. And in four cases, the President put a constitutional veto on laws. The Supreme Court declared two laws unconstitutional.

Regarding the legislative initiative, the Estonian Constitution allows the President of the Republic to have only the right to propose constitutional amendments. However, constitutional amendments are not permitted during emergency or war situations. Although the President has no right to propose laws, he or she may exert an indirect influence on adopting laws where, at the request of the Parliament, he or she gives an opinion on an issue (Article 74 of the Constitution). The President also issues instruments for the ratification of international treaties.

The President of the Republic calls elections for the Parliament and convenes the first sitting of the newly elected Parliament. The President of the Parliament may propose to convene an extraordinary sitting. The President of the Republic dissolves the Parliament and calls elections if it is not possible to form a government. The President of the Republic may dissolve the Parliament upon the Prime Minister's proposal if a vote of no confidence in the Government or Prime Minister passes (Article 97 of the Constitution). The latter reason for the dissolution of the Parliament differs from others because in this case, the President of the Republic autonomously decides whether or not to dissolve the Parliament. In other situations, however, to dissolute the Parliament is not merely a right, but also an obligation when under the Constitution, certain circumstances occur. Furthermore, in accordance with Article 105 of the Constitution, the President shall dissolve the Parliament and call the elections when voters do not approve the law in the legislative referendum called by the Parliament. The same also applies when the Parliament does not adopt the budget on time, i.e., within two months from the beginning of the budget year (Article 119 of the Constitution).

In regard to appointments, the President of the Republic, inter alia, has the right to present the Parliament with the proposals for appointing the Chancellor of 
Justice $^{14}$, the National Bank's Management Board Chairman, the President of the Court of Auditors, Ombudsman, and the President of the Supreme Court. On the latter's proposal, the Parliament appoints the rest of the Supreme Court judges.

\subsection{Powers in the Executive Realm}

The important executive powers the President of the Republic has are his or her mandatory powers. It is about the powers that the President has when appointing the formateur and individual ministers. In most European countries, the President of the Republic shall appoint the Prime Minister who must then (alone or with the already formed government) win the confidence (investiture) vote in the Parliament. A different situation is in Slovenia where the Prime Minister is elected by the Parliament upon the proposal of the President of the Republic. According to the Estonian constitutional order, the President of the Republic shall appoint the candidate for the Prime Minister. If the candidate wins a vote of confidence in the Parliament, he or she shall form a government. Within 7 days, the candidate shall present the Government to the President of the Republic who shall appoint its members. On the Prime Minister's proposal, the President of the Republic shall also dismiss the ministers. If the candidate appointed by the President of the Republic has not been certified by the Parliament, or he/she has failed to form the government, the President may appoint another candidate within 7 days. If the President of the Republic appoints no candidate in due time, or if also the second candidate nominated by the President has failed, the Parliament gets the right to nominate a candidate for the Prime Minister who must form a government within 14 days from the day when the right to nominate a candidate was transferred to the Parliament. The candidate must then present the new government to the President of the Republic (Article 89 of the Constitution). In the event of another failure, the President of the Republic shall dissolve the Parliament and call new elections. ${ }^{15}$

The Estonian Constitution lays down no countersignature for the acts of the President of the Republic with which the Prime Minister or individual ministers assume political responsibility for a decision made. It also provides the validity of the legal acts of the President. The Slovene Constitution does not know the institute of the countersignature ${ }^{16}$ either.

Regarding the appointment of some highest state officials, the President of the Republic, inter alia, has the right to appoint the Governor of the National Bank (upon the Bank Board's proposal). ${ }^{17}$

Upon the Supreme Court proposal, the President of the Republic appoints judges, which is in accordance with the most frequent President's cooperation in the process of appointing the judges in Europe. This refers to the appointment of judges by the Head of the State upon some other body's proposal (Nerad, 2004:59). The Slovene Constitutional order differs from the just mentioned because the President of the Republic of Slovenia is not competent to appoint the 
judges who are elected by the National Assembly on a proposal from the Judicial Council. $^{18}$

\subsection{Extraordinary Powers}

They refer to the powers the President of the Republic has in conditions that threaten the existence and security of the country. In accordance with Article 128 of the Constitution, the President of the Republic proposes to the Parliament to declare the state of war and emergency as well as the mobilization and demobilization measures. In the event of an attack, the President of the Republic himself declares the beginning and the end of the war state. Related to the extraordinary powers of the President of the Republic, the Constitution also stipulates that the President may issue legislative decrees (that need to be countersigned by the President of the Parliament and by the Prime Minister for validity) in cases of emergency when the Parliament cannot meet due to a state of emergency. Such decrees must be submitted to the Parliament for approval immediately after the Parliament meets (Article 109 of the Constitution).

\section{Responsibilities of the President of the Republic}

The President of the Republic enjoys immunity. Article 85 of the Constitution provides that the criminal prosecution against the President of the Republic may be started only upon the Chancellor of Justice's proposal, which must be approved by a majority in the Parliament. The President of the Republic shall be suspended from office until the decision by the Court. In accordance with Article 82 of the Constitution, the office of the President of the Republic terminates in the event of a final conviction.

\section{Conclusion}

The analysis of the position of the President of the Republic of Estonia has shown that his/her powers are mainly of the representative nature, which is also characteristic of a parliamentary system. In comparison with our and other primarily Eastern European constitutional orders, there are important and interesting differences. Thus, for example, Estonia (in addition to Slovenia) is the only country among the Central and Eastern European EU Member States that does not know the institute of the countersignature for the acts of the President of the Republic. In contrast to the Slovene Constitution, the Estonian Constitution acknowledges the President's right of suspensive veto within the legislative procedure. A suspensive veto might be useful also in the case of the Slovene President of the Republic to strengthen his office. In the sphere of mandatory powers, the Estonian President of the Republic has more impact on the formation of the government than the Slovene President. 
This paper has paid most attention to the elections of the Estonian President. As in most European countries, the acquisition of the passive right to vote is restricted by a higher age census. Here Slovenia stands out again because the conditions for the acquisition of the passive and active rights to vote are equal. The Estonian presidential election regulations, which anticipate up to five rounds of elections, are specific primarily due to the participation of local communities in four and five possible rounds when the President is elected by a special electoral body. Thus, the Estonian elections ${ }^{19}$ differ significantly from our regulations whose peculiarity is that, on the one hand, direct elections strengthen the position of the President, but on the other hand, they restrictively determine his powers. The facts indicated above merely confirm that the mode of election is not necessarily associated with the extent of the formally laid-down powers of the President of the Republic. When concluding, I can say that in Estonia there is a typical parliamentary system with an indirectly elected President of the Republic, and that in comparison with the Slovene President, his/her position is stronger, which is evident primarily in the President's powers in the executive and legislative realms.

\section{Notes}

1 Please see more on political systems: Schreyer, B., Schwarzmeier, M. (2005), Grundkurs Politikwissenschaft: Studium der politischen Systeme, (Wiesbaden: VS Verlag), pp 159-163 and Spörer, D. (2006), Regierungssysteme und Reformen, (Wiesbaden: VS Verlag), p 10.

2 Please see on the Estonian constitutional order: Laasch, J. (2002), Staat und Regierung in Estland, Europa Digital. Accessible at http://www.europa-digital.de/laender/est/staat/, 18.2.2008 and Bungs, D. (2004), Estland. Weidenfeld, W. (ur.), Europa Handbuch, Band 2: Die Staatenwelt Europas, pp 113-124 (Gütersloh: Verlag Bertelsmann Stiftung), and Schmidt, T. (2003), Die Aussenpolitik der baltischen Staaten, (Wiesbaden: VS Verlag), p 74.

${ }^{3}$ When representing the country abroad, the President of the Republic has no powers to autonomously form the foreign policy of the country. Therefore, in accordance with the principle of the separation of powers, the President of the Republic shall take into account the basic decisions made by the Parliament, and the Government policy. Ribarič, M. (2000), The Status of the President of the Republic of Slovenia in the Governance System, National report for the Round Table Conference "Ten Years of the Democratic Constitutionalism in Central and Eastern Europe". Accessible at http://www2.gov.si/up-rs/19922002/mk.nsf/17775b85e5d902fdc125678d003919c3?OpenView, 4.11. 2008.

${ }^{4}$ Please see more detailed information on the Estonian Supreme Court: Heitur, M., Haljasmäe, R., Kask, T., Leppik, M. (ur.) (2004), The Supreme Court of Estonia, (Tartu: Elmatar Publishing House).

${ }^{5}$ See, for example, Cerar, M. (1997), The Position and the Role of the President of the Republic of Slovenia, Theory and Practice, Vol. 24, No 5, p 777. Please see more information on the position of the President of the Republic of Slovenia: Rupnik, J., Cijan, R., Grafenauer, B. (1996), Constitutional Law of the Republic of Slovenia, Special Part, (Maribor: Faculty of Law), p 193, and Kaučič, I., Grad, F. (2000), Constitutional Order of Slovenia, (Ljubljana: GV), p 251. Please see also Ribarič, M., (2002), The Powers of the President of the Republic. Šturm, L. (ur.), Comment on the Constitution of the Republic of Slovenia, p 836, (Ljubljana: Faculty of Postgraduate National and European Studies). 
${ }^{6}$ The President of the Republic of Estonia is Toomas Hendrik Ilves who was elected in 2006. In the first three rounds of elections, Ilves did not get the required two-thirds majority. In the fifth round, in which the President was elected by a special electoral body, Ilves got 174 votes out of 345 members. Please see Estonia Today - Presidential elections (2006), (Tallinn: Press and Information Department, Ministry of Foreign Affairs). Accessible at http://webstatic.vm.ee/static/failid/422/Presidential_elections_2006.pdf, 4.11.2008.

${ }^{7}$ See also Brodocz, A., Vorländer, H. (2006), Estland: Verfassung, Europa, (Bonn: Bpb). Accessible at http://www.bpb.de/themen/7GWU95,0,0,Verfassung.html, 5.2.2008.

8 On the presidential election in Eastern Europe: Ismayr, W. (2004), Die politischen Systeme der EU-Beitrittsländer im Vergleich, Das Parlament - Aus Politik und Zeitgeschichte, (Bonn: Bpb), pp 5-15.

${ }_{9}$ Information published in Local Government in Estonia (2005), (Tallinn: Ministry of the Interior Department of Local Government and Regional Administration), pp 2-3. Accessible at http://www.siseministeerium.ee/public/LGinEstonia2005_20070322090339.pdf, 4.10.2008. Compare Brezovnik, B. (2008), Decentralisation in Theory and Practice, Lex localis, Vol. 6, No 1, p 94. See also Medved, A. (2008), Territorial Subdivisions of the Republic of Estonia. Kocbek, M., Budja, A. (ur.), Territorial Subdivisions in EU Member States, (Maribor: Lex localis) p 39. On the local self-government in our country, please see Grafenauer, B. (2000), Local Self-Government in Slovenia: Territorial and Organisational Structures, (Maribor: Faculty of Law).

10 Information published in Estonia Today - Presidential elections (2006), (Tallinn: Press and Information Department, Ministry of Foreign Affairs). Accessible at http://web-static.vm.ee/static/failid/422/Presidential_elections_2006.pdf, 4.11.2008.

11 For more information on the 2001 presidential election, please see Constitution Watch Estonia (2001), East European Constitutional Review, Vol. 10, No 4.

${ }^{12}$ For more information on the powers and position of the President of the Republic of Estonia, please see Lucky, C. (1993), A Comparative Chart of Presidential Powers in Eastern Europe, East European Constitutional Review, Vol. 2, No 4 / Vol. 3, No 1, pp 81-94 where, when comparing the powers of the presidents in East-European countries, the author specifies the constitutional powers of individual presidents and thereby taking into account whether a president implements his/her powers autonomously or together with other body. Please see also Frye, T. (1997), A Politics of Institutional Choice: Post-Communist Presidencies, Comparative Political Studies, Vol. 30, No 5, pp 523-552 where the author gives a more detailed analysis of the position of the president to assess 27 powers of the president of the republic (inter alia, the following powers are relevant: the right to dissolve the parliament, to call elections, to nominate the prime minister and ministers, to appoint judges and the supreme public prosecutor, to be the supreme commander of defence forces, to have the legislative or constitutional veto right, to have a legislative initiative, to propose constitutional amendments, to convene or to call for convocation of an extraordinary sitting of the parliament, to send opinions to the parliament, to have the option of participating in the parliament and government sittings where it must be taken into account whether the president implements his powers by himself or in cooperation with somebody else. Also written about by Siaroff, A. (2003), Comparative presidencies: The Inadequacy of the Presidential, Semi-Presidential and Parliamentary Distinction, European Journal of Political Research, Vol. 42, No 3, pp 287-312. The author gives an analysis of the presidential powers in forming a government, in dissolving the parliament, in foreign policy; the author also analyses the president's extraordinary powers, his/her powers in appointments, his/her right to participate in the government sittings, and his/her right to put a suspensive veto on something. Siaroff also considers the presidential election mode to be a criterion.

${ }^{13}$ For more information on the legislative and constitutional veto, please read Ismayr, W. (2006), Die politischen Systeme Osteuropas im Vergleich. Ismayr, W. (ur.), Die politischen Systeme Osteuropas, (Wiesbaden: Vs Verlag), p 23. 
14 Chancellor of Justice is an independent official who monitors the constitutionality and legality of the executive and legislative branch of government. Upon the proposal of the President of the Republic, the Chancellor of Justice is appointed by the Parliament for the 7year period (Articles 139 and 140 of the Constitution).

15 Also written about by Lagerspetz, M., Maier, K. (2006), Das politische System Estlands. Ismayr, W. (ur.), Die politischen Systeme Osteuropas, (Wiesbaden: Vs Verlag), p 75.

${ }^{16}$ Countersignature written about also by Zagorc, S. (2004), The Institute of the Countersignature for the Acts of the Head of the State, master's thesis, (Ljubljana: Faculty of Law), p 36.

${ }^{17}$ In 2000, complications occurred in appointing the Governor of the National Bank when the President refused to appoint the candidate nominated by the Bank's Management Board. The crisis was quickly resolved after the bank had nominated another candidate who was appointed the National Bank Governor by the President. For more information, please see Constitution Watch - Estonia (2000), East European Constitutional Review, Vol. 9, No 3.

${ }^{18}$ Ribaric believes that it would be advisable to amend the Slovene Constitution so that judges would be appointed by the President of the Republic upon the proposal of the appropriate Judicial Council with the participation of the Minister of Justice. Please see Ribarič, M. (2001), The Institution of the President of the Republic on the Tenth Anniversary of the Constitution, VII Public Law Days, (Ljubljana: Public Administration Institute), pp 105-119.

${ }^{19}$ It should be pointed out that Estonia is the only country in which state-level elections are held on the Internet and voters may vote at home. Please see Toplak, J., Hodnik, A. (2006), Electronic Ballot in Elections - Experience and Dilemmas in the Selected Countries, Law Faculty Miscellany of the University of Maribor, Vol. 2, pp 51-67.

\section{References}

Brezovnik, B. (2008), Decentralizacija v teoriji in praksi, Lex localis, 6(1), pp. 87-103

Brodocz, A., Vorländer, H. (2006), Estland: Verfassung, Europa, (Bonn: Bpb), www.bpb.de (6. november 2008)

Bungs, D. (2004), Estland. Weidenfeld, W. (ur.), Europa Handbuch, Band 2: Die Staatenwelt Europas, str. 113-124 (Gütersloh: Verlag Bertelsmann Stiftung)

Cerar, M. (1997), Položaj in vloga predsednika Republike Slovenije, Teorija in praksa, 24(5), pp. 763-781

Constitution Watch - Estonia (2000), East European Constitutional Review, 9(3).

Constitution Watch - Estonia (2001), East European Constitutional Review, 10(4).

Dubrovnik, T. (2008), Položaj šefa dř̌ave v vžhodnoevropskib državah članicah EU, diplomska naloga, (Maribor: Pravna fakulteta)

Estonia Today - Presidential elections (2006), (Tallinn: Press and Information Department, Ministry of Foreign Affairs)

Frye, T. (1997), A Politics of Institutional Choice: Post-Communist Presidencies, Comparative Political Studies, 30(5), pp. 523-552

Grafenauer, B. (2000), Lokalna samouprava na Slovenskem: teritorialno-organizacijske strukture, (Maribor: Pravna fakulteta)

Heitur, M., Haljasmäe, R., Kask, T., Leppik, M. (ur.) (2004), The Supreme Court of Estonia, (Tartu: Elmatar Publishing House)

Ismayr, W. (2004), Die politischen Systeme der EU-Beitrittsländer im Vergleich, Das Parlament - Aus Politik. und Zeitgeschichte, (Bonn: Bpb)

Ismayr, W. (2006), Die politischen Systeme Osteuropas im Vergleich. Ismayr, W. (ur.), Die politischen Systeme Osteuropas, pp. 9-69, (Wiesbaden: Vs Verlag)

Kaučič, I. (1995), Funkcije predsednika republike in državni zbor, 1. strokovno srečanje pravnikov s področja javnega prava, (Ljubljana: Inštitut za javno upravo), pp. 257-272 
Kaučič, I., Grad, F. (2000), Ustavna ureditev Slovenije, (Ljubljana: GV)

Laasch, J. (2002), Staat und Regierung in Estland, Europa Digital, www.europa-digital.de (6. november 2008)

Lagerspetz, M., Maier, K. (2006), Das politische System Estlands. Ismayr, W. (ur.), Die politischen Systeme Osteuropas, pp. 71-110, (Wiesbaden: Vs Verlag)

Local Government in Estonia (2005), (Tallinn: Ministry of the Interior Department of Local Government and Regional Administration)

Lucky, C. (1993), A Comparative Chart of Presidential Powers in Eastern Europe, East European Constitutional Review, 2(4) / 3(1), pp. 81-94

Medved, A. (2008), Teritorialne členitve Republike Estonije. Kocbek, M., Budja, A. (ur.), Teritorialne clenitve v dræ̌avah članicah Evropske unije, pp. 39, (Maribor: Lex localis)

Nerad, S. (2004), Razmerje predsednika republike do sodne oblasti, X. dnevi javnega prava, (Ljubljana: Inštitut za javno upravo), str. 57-72

Ribarič, M. (2000), Status Predsednika Republike Slovenije v sistemu vladanja, National report for the Round Table Conference "Ten Years of the Democratic Constitutionalism in Central and Eastern Europe"

Ribarič, M. (2001), Institucija predsednika republike ob 10-letnici ustave, VII. Dnevi javnega prava, (Ljubljana: Inštitut za javno upravo), pp. 105-119

Ribarič, M., (2002), Pristojnosti predsednika republike. Šturm, L. (ed.), Komentar Ustave Republike Slovenije, pp. 836, (Ljubljana: Fakulteta za podiplomske državne in evropske študije)

Rupnik, J., Cijan, R., Grafenauer, B. (1996), Ustavno pravo Republike Slovenije, Posebni del, (Maribor: Pravna fakulteta)

Schmidt, T. (2003), Die Aussenpolitike der baltischen Staaten, (Wiesbaden: VS Verlag)

Schreyer, B., Schwarzmeier, M. (2005), Grundkurs Politikwissenschaft: Studium der politischen Systeme, (Wiesbaden: VS Verlag)

Siaroff, A. (2003), Comparative presidencies: The Inadequacy of the Presidential, SemiPresidential and Parliamentary Distinction, European Journal of Political Research, 42(3), pp. 287-312.

Spörer, D. (2006), Regierungssysteme und Reformen, (Wiesbaden: VS Verlag)

Toplak, J., Hodnik, A. (2006), Elektronsko glasovanje na volitvah - izkušnje in dileme izbranih držav = Electronic ballot in elections - experiences and dilemmas in the selected states, Zbornik Pravne fakultete Univerze v Mariboru, 2, pp. 51-67.

Zagorc, S. (2004), Institut protipodpisa aktov šefa dř̌ave, magistrska naloga, (Ljubljana: Pravna fakulteta) 